Article

\title{
The Work of Art Criticism: Collaboration, Communication, Community
}

\section{Matthew Bowman}

School of (EAST) Engineering, Arts, Science \& Technology, University of Suffolk, Ipswich IP4 1QJ, UK; m.bowman@uos.ac.uk

Received: 14 August 2020; Accepted: 23 September 2020; Published: 29 September 2020

\begin{abstract}
This essay aims to reconsider the practice of art criticism. The first part aims to clear away some misconceptions that reduce art criticism to a fundamentally negative discourse that asserts a theory/practice distinction. In the second part, the essay tries to think of art criticism as collaborative writing alongside rather than about an artist. The third part, however, highlights some problems insofar as communication and collaboration have become imbricated within post-Fordist socioeconomic frameworks. In addition, the fourth part seeks to propose another direction by suggesting why art criticism and Kantian aesthetics may discover a renewed interest in one another through rethinking the sensus communis as an alternative to post-Fordist sociality.
\end{abstract}

Keywords: art criticism; aesthetics; post-Fordism; Kant; collaboration; October

\section{Some Definitions, Some Problems}

To tell the truth, I am not normally given to quoting my father on matters relating to art-not because he was unintelligent, but because he had expressly little interest in the subject-and I should perhaps feel somewhat guilty for doing so as his view is one that I shall be explicitly rejecting. However, I recall getting into a conversation with him some time ago about what I do and him commenting, "the problem with art critics is that they are employed to criticize. The clue is in the name". At that point, I tried to explain the etymology of the words "critic" and "critique" and that criticism is not about merely criticizing-I am not sure how much effect my entreaty had, but his view stuck in my head as it seems representative of the typical straw man arguments that are not infrequently arraigned against art criticism (in this regard, reading the art criticism on the Guardian website tends to be an almost dispiriting experience for me: the standard of the criticism written there is not great, to be sure, but the responses below mostly either rail against contemporary art as "con art" or claim that art critics, in general, lack the requisite talent to be an artist and so their art-critical writing is an expression-apparently often embittered —of that lack). More recently, at a private viewing, an artist colleague of mine remarked that "art theorists" - which are for him are coextensive with art critics and art historians-“"are like eunuchs at an orgy"1.

In relating these anecdotes, my intention is not to suggest that I was stung by their comments (which, strangely enough, amount to criticisms of criticism, and, on occasion, criticize the art critic for criticizing). Instead, what I wish to do is suggest that such quotidian remarks indicate, in microcosm, the oft-repeated misconceptions of the function of art criticism and, hopefully, by identifying such misconceptions, we can suggest a more productive understanding of this function, one that sees art criticism as a collaboration rather than, for instance, as mere opposition. What, then, are the misconceptions?

1 "Bollocks," was my reply, which, sadly, was as far as my wit went at that precise moment. 
The first of these misconceptions is the identification of art criticism with evaluative discourse as such - the critic supposedly wandering through the gallery (or Clement Greenberg standing in Jackson Pollock's studio), casting his vote upon artworks by pointing his thumb downwards or upwards. Evaluation has been one of the most vexed topics in art criticism, especially since the 1980s, when forms of postmodernism cognizant of our inherent perspectivalism questioned the evident imposition of one's necessarily limited and, ultimately, non-universal viewpoint over another. Although philosophers such as Noël Carroll propose that evaluation is central to any genuine art-critical enterprise (Carroll 2009; Diederichsen 2010), it has been argued by the likes of Rosalind Krauss that the more productive function of art criticism is a reflection upon method. As she writes:

Can it be argued that the interest of critical writing lies almost entirely in its method? Can it be held that the content of any given evaluative judgment- "this is good, important", "this is bad, trivial" - is not what serious criticism is, seriously, read for? But, rather, that such criticism is understood through the forms of its arguments, through the way that its method, in the process of constituting the object of its criticism, exposes to view those choices that precede and predetermine any act of judgment? (Krauss 1986, p. 1)

The second of the two anecdotes reflects the deeply entrenched theory versus practice divide, which recurrently places criticism — as well as the manifold of other written discourses on art-on the side of theory and so without proper access to practice embodied in or as the artwork. The theory/practice demarcation has a considerable history that cannot be plotted out here; but it is often commensurable with the parallel separation of the verbal and the visual, which maintains that writing about art is going to, in some measure, be distant from the artwork in itself and possibly even from our lived experience of that artwork (Baxandall 1986). Yet the assumed gap between theory and practice should not be so readily accepted; artists have frequently bridged the divide, after all, and artworks can become very theoretical insofar as they embody or can be situated in relation to theory. The Supports/Surface group in France, to give but one instance, expressly sought to examine painting in light of the theoretical positions developed by Philippe Sollers, Marcelin Pleynet, and Hubert Damisch, in and around the Tel Quel journal. And indeed, the notion of artistic research significant to contemporary practices and education in recent years is surely pledged to just this refusal of theory and practice as irrevocably discrete entities.

The assumed theory/practice divide has also been fuelled by developments in art since the emergence of modernism. Naturally, this statement would require enlisting a sustained historical account in order to secure its truth value, and this would take us far from the intentions of the present essay. However, it could be said-or pointed to-in brief outline that artistic practices that overtly rejected long-held standards and procedures in Western art, such as, for instance, Manet's paintings or the Impressionists, were met early on with incomprehension and ridicule by the general public. In saying this, I am not, obviously, offering something new; indeed, such conflict has been a reiterated story of modernism-almost a founding myth and perhaps a cliché-that has defined, in one way or another, the character of the movement. Nevertheless, the public pointing and laughing at Olympia is an ephemeral event. What remains are the writings by critics that shared in, and perhaps helped manufacture or voice the public's displeasure and incomprehension, and provided a lasting testimony recorded in the public sphere to this conflict (Clark 1985). Schooled to judge artworks conforming to traditional hierarchies, the art critics of the late nineteenth century and into the early twentieth century largely could only fervently decry the new forms of representation being born at the time. Admittedly, narrating this history so briefly misses out the nuances of the argument and casts a one-sided generalized understanding of art criticism; however, it does begin to suggest that the intense relationship between artist and critic, which would later inveigh upon the problem of evaluation, is contingently overdetermined by historical phenomena.

The question becomes, in that case, how we can configure a more productive correspondence between art criticism and artistic practice. Answering this question need not be only a theoretical 
and speculative affair, for it is possible to consider the matter at hand historically as well. In other words, just as we can look into the past and find plentiful examples of warring critics and artists, we can also find instances of collaborative activity with artists and critics reaching for the same goal or engaged in the same discursive field. It is also worth talking-and this shall be expanded upon as the essay progresses-about art criticism rather than art critics. The division of labor in the art world generally separates the art critic from the artist, thereby presenting these as different activities. This is not untrue, so far as it goes, but this particular division of labor risks proposing as a corollary that art and art criticism are potentially incommensurate and, hence, establishes the opposition-or rather the perception of the opposition-between art and art criticism tout court. By establishing this as an opposition from the get-go, the consequence is that any potential collaboration between art and criticism is blocked in advance, thereby also obstructing future possibilities.

My operating assumption, then, is that art criticism is an activity practicable by artists and curators as well as by art critics and is done so as artistic production and as exhibition-making. Research-based art, insofar as it often utilizes a discursive methodology alongside a commitment to theoretical and historical procedures, would seem to be on some level a type of art criticism. Going further, and at the risk of putting the matter too strongly, it can perhaps be argued that art criticism is the template for most of the discursive structures within artistic practice and the art world at large since the end of the 1960s. There are substantial problems implicated within this assumption insofar as it opens the possibility of the displacement of the art critic from the art field, or, at worse, even rings the death knell for the art critic. Such a displacement or death, some would argue, has already been codified by the expanding, more discursive, roles held by artists and curators alike since the emergence of conceptual art strategies during the latter portion of the 1960s. While these roles have greatly changed in their scope, it is not altogether obvious, perhaps, that a similar transformation has occurred within art criticism as such. After all, if art criticism is an activity incorporated within art and exhibition-making, then what need is there for the art critic as such?

Moreover, there has been a real worry-Benjamin Buchloh has voiced this concern, for instance-that art criticism has become powerless in the face of the primary and secondary art markets to such a degree that neither negative or positive art criticism appears to have much effect upon artwork values: "you don't need criticism for an investment structure, you need experts. You don't have criticism of blue-chip stocks either" (Baker et al. 2002, p. 202). While there is a ring of truth in these arguments, they also present the situation too pessimistically and often invoke a semi-mythical halcyon age where the art critic was king. And although the displacement of the art critic by the artist and curator might look like the prelude to his removal from the art field, we can equally speak of this displacement as being, in actuality, the expansion of art criticism that approximately tracks and overlaps with similar expansions in artistic practice. In any case, although I will indeed be referring to art critics and artists as independent entities, the general thrust of my remarks from here onwards would be that when art criticism as collaboration happens, then it is an event that occupies a dialogical space between the artist and the art critic and disrupts the traditional division of labor separating the two positions.

\section{Art Criticism as Collaboration}

So, then, how could we begin to think of art criticism as collaboration? In my own research, I have long been intrigued by the emergence of the October journal in the 1970s and its inclusion of theory taken from French post-structuralism as well as the writers of the Frankfurt School into its art-critical approach. Much of that theory was still fairly new in an Anglo-American context, with some of it having been only recently translated. Such theory was not being translated for its own intrinsic value, but also because it was strategically useful for delineating the parameters of an uncertainly-shaped postmodern culture, the existence of which was becoming increasingly evident at the time. Modernism, especially as exemplified by the writings of Clement Greenberg, was on the wane, and the critical significance of the new art being produced by younger artists in the late 1960s and the 1970s could not 
be secured by theoretical notions collectively designed in a different context. It became a matter of not simply rejecting Greenberg and his normative criteria of medium specificity, but of also discovering new concepts that can engender a positive account responsive to a new set of artistic concerns.

Although the term "postmodernism" was very much in use within architectural theory in the latter half of the 1970s, its precise meaning had yet to be fixed, and so different cultural producers engendered different postmodernisms. Thus, October was able to pick up "postmodernism" as a semi-empty signifier that could be then applied to emergent practices that eschewed Greenbergian medium specificity. This is to suggest that not only were art critics elaborating what postmodernism could potentially be but that artists were, too. The artworks themselves were a form of art criticism that interrogated and sought to go beyond their modernist predecessors; an essential aspect of the structural logic of these artworks was that they apprehended blind spots, limitations, and inconsistencies within the modernist project, thereby necessitating a new direction. In possessing this art-critical dimension, these emerging artistic practices served as theoretical objects demonstrating the novel possibilities available after modernism's closure. In this way, these practices generated a dialogical space that art criticism was able to enter. This is in no way to contend that the process was linear and one-directional, nor is it to suggest that the contours of this space were fixed by art practices. Rather, a key element of this space was precisely its openness to dialogue between art and criticism, which thereby defined and redefined its structure.

In an interview that was conducted towards the end of his life before AIDS took its toll, the former October editor and critic Craig Owens reflects upon the relationship between artists and critics in the late 1970s and into the 1980s. At one stage of the interview, Owens reveals his skepticism about the division of labor that demarcates the critic from the artist insofar as it serves "to treat the work of art as a symptom" and places "the artist in the position of the unconscious reflex and the critic in the position of the diagnostician". Against this privileging of the art critic and the reduction of the artist to the pre-reflexive, Owens resituates his own practice:

The split between critic and artist, then, had been compromised, and we were writing not necessarily about these critical and opposition practices but alongside them. There was an exchange there, and one's criticism was conducting the same work in a different arena and in a different way. I feel that that way about, say, Barbara Kruger's work and my work. (Stephanson 1992, p. 307)

To some degree, this resituating was made virtually necessary by art's embrace of discursivity in the 1960s. Pop Art, Minimalism, and Conceptual Art foregrounded linguistic structures and the materiality of the word-sign in their respective practices, although in varying ways and to different ends. For example, in Pop, writing follows the pictorialized lettering of branding as well as the narrativity of the comic book, thereby destabilizing the traditional opposition between image and text by highlighting the latter's visual qualities. And differing mostly in emphasis but sharing a drive towards auto-critique or reflexivity, Minimalism used philosophical discourse as part of the explication of its serial forms, whereas Conceptualism often made that discourse its form. It is almost as if the hegemony of abstraction underpinned by Greenberg's art-critical apparatus was best countered through attacking that apparatus by mirroring and replicating the discursivity specific to it rather than via direct assault upon abstraction itself.

If art criticism increasingly became conjoined with artistic practice, however, then one might be concerned that the chief function of such "artist's criticism" might not so much be about inducing reflexivity or explicating the artwork as it is actively to pre-empt the work of art criticism. In his essay "Music Discomposed", the philosopher Stanley Cavell articulates-with a certain degree of ambiguity-this type of worry: "The issue is simply this: we know that criticism ought to come only after the fact of art, but we cannot ensure that it will come only after the fact" (Cavell 2002, p. 209). Which is to say, art criticism might actually precede the artwork and set the conditions for its appearance, or it might not even happen at all. A similar worry is evident in Michael Fried's 1967 essay "Art and Objecthood"; his inclination to refer to Minimalist art as "Literalism" not only betokens his twinned 
argument against what he perceives as Minimalism's hypostatization of objecthood as such, conjoined with its literalizing reading of Greenberg's criticism, but also, implicitly, suggests a peculiarly "literary" quality internalized by Minimalism. As Fried puts it at the start of his essay: "[Literalism] is largely ideological. It seeks to declare and occupy a position-one that can be formulated in words and in fact has been so formulated by some of its leading practitioners" (Fried 1998, p. 148; emphasis is mine). To contend, as both Cavell and Fried implicitly do, that art criticism deployed by artists might pre-empt the art criticism produced by art critics forgets that art criticism of whatever origin is open to further explication, dialogue, interpretation, and, indeed, art criticism, all of which surely count as collaborative modes, or what Maurice Blanchot might term an "infinite conversation".

For Owens, in a couple of important essays written for October early in its publication history, these developments signaled a momentous change in artistic practice. In his essay "Earthwords", Owens argues that the writings produced in the 1960s were qualitatively different from those that were made within the European avant-garde movements before the Second World War. On that score, it might be assumed that Owens' model for art-critical writing alongside artworks is interlinked with the linguistic turn of the 1960s- “the eruption of language into the field of the visual arts and the subsequent decentering of that field" (Owens 1979, p. 122). The evidence for this claim seems reasonable when we consider, for instance, Mel Bochner's 1966 exhibition Language to be Looked at and/or Things to be Read, where the mutual convertibility amid the visual and the verbal is stressed. This interchange permits the possibility for art criticism as a collaborative practice, even if, it might be argued, that Owens' contention here rests upon an over-simplification of the writerly activities occurring in pre-war European modernism that fails to recognize collaborative and discursive practices in those avant-gardes. Nonetheless, within 1960s and 1970s Conceptual Art, there is a wide-ranging engagement with textuality, as the name of the group Art \& Language indicates. This deeply rooted interchangeableness of the visual and the verbal leads Owens to conceive the writings of Robert Smithson et al. not as secondary activities designed to elucidate something obscure in their works or as compensatory gestures meant to fill some lack; they are not, in other words, supplements to the visual (unless one, of course, understands supplement in the strictly Derridean sense (Derrida 1976)).

And yet, if there are also bountiful examples of textual practice within modernist art, then how can that art be categorically demarcated from the specific eruption of language spotlighted by Owens? Owens argues that it is no doubt true that writing has had an important role in modernism-one only need think of Matisse, Malevich's The Non-Objective World, Kandinsky's Concerning the Spiritual in Art, Mondrian's Plastic Art and Pure Plastic Art, or Breton's Surrealist Manifestos_but a qualitative difference has occurred: modernist writings, Owens contends, following Roland Barthes, issue from the quasi-theological standpoint of the author-God, whereas Smithson and others of his generation, Owens argues, primarily produces texts. The textual nature of Smithson's enterprise is not restricted to the production of essays but inflects the entirety of his practice. The play of the textual-the incessant reciprocity between the visual and the verbal-must be correctly understood: in Smithson's work, the textual aspect is in no respect a mere appendage; his art does not serve as the visualized expression of the ideas and essays contained in his essays, nor does the writing act as an exposition or clarification of the intent of his artwork - it is frequently the case that Smithson's writings are as opaque and as mysterious as the works they relate to (Smithson 1996). And importantly, despite the emphasis given to the verbal by Owens and Smithson alike, neither would argue that the activity of writing subsumes or replaces the visual aspects; the documentation/essay Incidents of Mirror Travel in the Yucatan does not become a work of art by virtue of replacing an ensemble of sited mirror interventions that are inaccessible except through writing and photography; rather, the work of art materializes precisely from the dialectic between magazine spread and landscape, that is to say, between site and non-site.

Take, for example, the textuality that emerges from-or, rather, is the condition of possibility for-the dialectic between site and non-site in Smithson's Spiral Jetty. For where is one precisely to locate this work by Smithson? As is well known, the name Spiral Jetty designates a plurality of instances: an earthwork made of rock situated on the Great Salt Lake in Utah, a film that shows 
the making of the earthwork, an essay that narrates Smithson's reasons in building this earthwork, and various photographs, diagrams, maps, and graphs that all contribute to the research undertaken by Smithson. Properly speaking, Spiral Jetty nominates each one of these instances separately as well as their convergences. Moreover, it attests to the displacement of each instance into the other, and we might imagine this happening not in the sense that this displacement might run linearly, as if in a chain, but in the sense that this displacement happens within a complex network in which no instance has priority over, or is automatically temporally before, the other. Each instance, if we may paraphrase Adorno, can be seen as a fragment of a greater whole, to which, however, they do not quite add up. That is the "postmodern"-but also perhaps the more or less "early romantic", in the sense of the Athaneum circle of writers discussed by Philippe Lacoue-Labarthe and Jean-Luc Nancy in their joint-authored The Literary Absolute (Philippe and Nancy [1978] 1988)—condition of Smithson's "earthwords."

Smithson's artworks specialize in this incessant hybridization and cross-wiring. Never totally here and never totally there, spatially or temporally, much of Smithson's production deliberately prises apart and literally deconstructs the basic rigid categorizations that constitute Greenbergian modernism. For that reason, Smithson possesses an obvious degree of strategic importance for Owens and for developing an account of postmodernism, because it is Smithson's oeuvre that offers Owens an exemplary narrative of the visualization of textuality and of the textualization of the visible, the spatialization of time and the temporalization of space-all of which help to delineate for Owens an emergent postmodern sensibility.

Complex works such as Incidents of Mirror Travel in the Yucatan and Spiral Jetty, with their geological, mythical, and scholarly methodologies, could be regarded as the precursors to contemporary research-based practices. In that sense, the inclusion and transformation of art criticism within the structure of these historical works also serve as a template for more recent manifestations. But I think that Owens perceives a further consequence of the interplay between criticism and practice. For not only does practice inject criticism within itself, but art criticism correspondingly becomes more practice-like; as a result, an alternative relationship between the artwork and critic is imagined. This possibility becomes more overtly expressed in Owens' next essay for October, "The Allegorical Impulse: Toward a Theory of Postmodernism", which sought to readdress the much-maligned concept of allegory as a means of defining postmodernism. There is not space here for a full discussion of that essay, but it is relevant for our purposes that Owens describes the allegorical impulse in postmodern art as being a textual impulse, an impulse that seemingly betokens criticism. For example, he writes early on: "Let us say for the moment that allegory occurs whenever one text is doubled by another ... [This] accounts for both allegory's origin in commentary and exegesis, as well as its continued affinity with them: as Northrop Frye indicates, allegorical work tends to prescribe the direction of its own commentary. It is this metatextual aspect that is invoked whenever allegory is attacked as interpretation merely appended post facto to a work, a rhetorical ornament or flourish" (Owens 1980, pp. 68-69). Here, criticism and practice appear to correlate, perhaps even become reflections or displacements of one another. Criticism both constitutes and is constituted by its object.

At this juncture, it could be suggested that this back-and-forth between criticism and art, as well as the continued presence of criticism within art, becomes especially unequivocal in the late 1980s-that is, at the point where research-led practice becomes especially prevalent within the art world and soon results in discussions about locational identity and pseudo-ethnography (Foster 1996). Artists such as Andrea Fraser, Mark Dion, and Renée Green, who constituted a second-generation Institutional Critique, all studied in the influential Whitney Independent Study Program and had critics such as Owens and Benjamin Buchloh as teachers. In that regard, Owens and Buchloh art-critically mediated the reception of 1960s discursivity for the students-perhaps codifying the notion of a first-generation Institutional Critique consisting of Michael Asher, Marcel Broodthaers, Daniel Buren, and Hans Haacke around this point. Later on, this would help to establish the intellectual conditions for exhibitions such as Kontext Kunst and Culture in Action that updated Institutional Critique practice in many respects. 
It could be argued that the notion of a first generation of Institutional Critique was still in the process of being developed by critics reflecting upon the counter-institutional practices of the late 1960s, in tandem with the concurrent rise of alternative spaces, who were facing the decay of the viability of such practices as well as persistent Republican assaults against funding for alternative spaces. In the light of the political situation in the art world during the 1980s, forms of anti-institutional oppositionality originating in the 1960s had come to seem near impossible and were thus retroactively reinvented and categorized by critics as Institutional Critique, a type of art that achieves its criticality through working parasitically within rather than outside institutions. This categorization was developed by critics such as Buchloh and Owens in correspondence with students such as Fraser and Green (Fraser 2006).

All this suggests some speculations and conclusions-or, rather, speculative conclusions-that are worth closing this section with. Firstly, as has been suggested, art criticism need not be something practiced by the professional art critic or as writing. Rather, as art history has shown, the artist can incorporate criticism into their art as their art. Although that claim might sound merely analogical, it appears plausible if we understand artworks as points within networks engaged in complex operations of replication - repetition, revision, and refusal_of other artworks in the network (Davis 1996). To that extent, then, the downplaying of art criticism's relevance or usefulness, often spoken of as the crisis of criticism, is only part of the story; art criticism by the critic may struggle against the market, but art criticism as art is another matter altogether. Secondly, and this shall be a contention that is difficult to substantiate but is surely worth throwing in, art criticism is at the heart of recent artistic research tendencies, perhaps even its template. Proposing this idea engenders the recognition that the model for artistic research is neither science nor technocratic modes of political thought, and so its judgments as artistic research are not answerable to those specific types of criteria, hypothesis, and falsification. Thirdly, art criticism by the critic, therefore, finds its mirror image in artistic research, thereby entailing the possibility of dialogue between the two. And finally, the old categorical separation of theory and practice is not going to hold in this context.

\section{Critique, Research, and Work: More Problems}

I wish now to address the word "work" that is inserted into the paper's title and touch upon recent discussions of post-Fordist labor and elements of contemporary capitalism insofar as these pose serious questions of both art-as-research and criticism. Indeed, the growth of notions of artistic research has gone hand-in-hand with a worry that such artistic research is entrapped within the strictures of post-Fordism, thereby limiting its capacity for cultural critique.

A quick way of entering into this realm of discussion is through the synonyms proposed for post-Fordism: variously, it has been described as "cognitive capitalism", aligned with the "knowledge economy", construed as a "network society", theorized as "semiocapitalism", and has links with neo-liberalism. More precisely, the shift from Fordism to post-Fordism is comprehended as a transition from an industrial-based economy (named after Henry Ford and the Ford motor car) to forms of immaterial labor, services, and the growth of the precariat (laborers who have little choice but short-term contracts with uncertain prospects for renewal, for example). Financialization is, of course, another cornerstone of a post-Fordist economy. One of the dominant effects of post-Fordism is to confuse decisively or render fluid the distinction between work and leisure; this is something that we see, for example, in forms of advertising, such as the following from Starbucks: "But, when you buy Starbucks, whether you realize it or not, you're buying into something bigger than a cup of coffee. You're buying into a coffee ethic ... Oh, and a little bit of the price of a cup of Starbucks coffee helps furnish the place with comfy chairs, good music, and the right atmosphere to dream, work and chat in. We all need places like that these days". Or this, from Microsoft's ad campaign for the New Busy: "THE NEW BUSY is not like the old busy. THE NEW BUSY navigates the worlds of work, leisure, friends, and family like a Pacific salmon".

Published in France in 1999, and translated into English during 2007, Luc Boltanski and Ève Chiapello's book The New Spirit of Capitalism provides an in-depth sociological analysis of 
these economic changes-especially as these appertain to France but also with a general applicability to other nation states. Historically situated as a counter-response to Fordist capitalism, they argue, were two modes of critique, namely, social critique (which focuses on inequality, poverty, egoism, and exploitation) and artistic critique, which, in Boltanski's words "criticizes oppression in the capitalist world (the domination of the market, the discipline of the factory), the uniformity of mass society and the commodification of everything, and it valorises an ideal of liberation and individual autonomy, of uniqueness and authenticity" (Boltanski 2008, p. 55). Although identified as two different types of critique, insofar as capitalism is their mutual target, then social and artistic critique may be regarded as two sides of the same coin. Artistic critique is not here the same thing as art criticism but, rather, is closer to artistic practice and names attributes that may be found in both artistic practice and art criticism (to an extent, art criticism might function somewhere between social and art critique). Historically, Boltanski and Chiapello argue, social critique would be more prevalent than artistic critique, which is mostly restricted to particular avant-garde circles.

In their analysis, the events of May 1968 represented a moment of crisis for French capitalism (again, this is generalizable to include Europe, as such, and the United States) and, moreover, social and artistic critique operating more or less equally and in tandem. Their main argument, though, is that in order to recover itself after May '68, capitalism elected to internalize elements of artistic critique. Thus, the ideal of liberation is transliterated into employment flexibility and the oppressive discipline of the factory - exemplified by people working on a line, each silently and quasi-solitarily focused upon their specific task-with more communicational modes of labor. To be sure, these changes are not universal, insofar as low-skill, agricultural, industrial forms of labor retain a strong presence within societies, but the overall drift of capitalism towards immaterial labor and products or, perhaps more accurately, the invention of techniques and technologies for accommodating communication as the production of economic value, is abundantly plausible. For other theorists of post-Fordism, such as Christian Marazzi and Paolo Virno, it is this burgeoning linguistic dimension of capitalism, the preponderance of communication and communication technologies, which is central to post-Fordism and generates the rise of its cognate terminological descriptions of "cognitive capitalism" and the "knowledge economy". For instance, Maurizio Lazzarato writes in his essay "Immaterial Labor" (and note the reference to "artistic standards"):

As regards the activity that produces the "cultural content" of the commodity, immaterial labor involves a series of activities that are not normally recognized as "work" - in other words, the kinds of activities involved in defining and fixing cultural and artistic standards, fashions, tastes, consumer norms, and, more strategically, public opinion. Once the privileged domain of the bourgeoisie and its children, these activities have, since the end of the 1970s, become the domain of what we have come to define as "mass intellectuality" ... [Post-Fordism has transformed] the role and function of intellectuals and their activities within society. (Lazzarato 1996, pp. 133-34)

Returning to Boltanski and Chiapello, this communicational aspect emphasizes the significance of networking and collaboration. The situation, however, is dialectical: while networks and communication indeed sound laudable, these values are more enforced through socialized guilt complexes than freely chosen in post-Fordism. As Boltanski and Chiapello write: "In a connexionist world, loyalty to the self looks like inflexibility; resistance to others seems like a refusal to make connections ... In a network world, the question of authenticity can no longer be formally posed" (Boltanski and Chiapello 2005, p. 451). If we understand the art world as itself a "connexionist world", as it surely is, then the formulation of independent art-critical judgments become troublesome as they risk endangering potential collaborative possibilities (Graw 2012). Meanwhile, such possibilities are, in themselves, somewhat questionable according to the terms of this argument, and the presence of collaboration and participation in much artistic research can begin to appear suspicious. 
In running through these post-Fordist theories, it becomes manifest that the logic of discursivity immanent to criticism and research worryingly resembles the communicational systems that underpin our current reign of capitalism. And this provokes difficult questions, not so much about the possibility of collaboration between criticism and research-on the contrary, such a possibility is virtually guaranteed by post-Fordism-but rather about its potential oppositionality. As one of the most important commentators upon artistic research, Tom Holert, has remarked:

The academic reorganization of art education and artistic practice, a development to which artistic research makes a not-insignificant contribution, is immediately integrated into transnational processes of the economization and corporatization of higher education. Translating "knowledge" into a productive force, converting it into a salable good, and marketing it as a spectacle-these are the central elements of the "global university's" mission. And it is here that it converges with the imagery and knowledge industries of "contemporary art", whose art fairs, biennials, conference events, and global museum corporations (including their offshore branches) aim to establish commercially valuable relations of equivalence between art, knowledge, and affects. (Holert 2011, p. 44)

Therefore, the problem faced by artistic research and criticism widens to include the social institutions - the universities, academies, and galleries-that host such activities. If research and criticism are desirable for the post-Fordist knowledge economy, then what hope for their oppositionality? What models of artistic agency are we left with in a situation when subjectivity itself becomes commercially valuable? In less subtle hands, this problem is unavoidable, and yet its non-specificity can lead to analytical totalizations that, unfortunately, render opposition null and void. But it is useful, to my mind, to resist confusing social forms with particular contents. While research and criticism as processes or forms are shared alike by artistic research and post-Fordism, their aims and contents differ markedly: the promise of wealth and the replication of social hegemony for a particular class is at sharp variance from the numerous ever-changing and significantly localized aims of much artistic practice. Hence, the outpouring of educational formats in art practices and the heightened discursivity produced through talks and symposia accompanying exhibitions can be construed as acknowledgments of this difference between form and content; in this way, the fatalism one occasionally finds in art world discussions on post-Fordism can be resisted in some respects.

Regrettably, there are no easy solutions to the problems just identified beyond a certain specificity of context. But maybe this contextual dimension is all-important in some measure. Following the phenomenological philosophy of Edmund Husserl with a degree of looseness, it might be remarked that art criticism is essentially defined by its "intentional structure". By intentionality, Husserl sought to present consciousness irrevocably as the consciousness of something, and this "of something" was determinative for there being any consciousness at all. Along similar lines, art criticism only counts as criticism through its relation to the something that it is criticism of; likewise, artistic research is also comported towards something and is therefore thoroughly situational. This suggests that art criticism and research are relational processes dependent on particular contexts for their contents, and insofar as these contexts are highly variable, then instances can only be examined on a case-by-case basis. The recruitment of criticism and research for post-Fordist capitalism, then, is far from predestined.

\section{An Aesthetic Turn?}

Permit me to give another anecdote. James Elkins generously allowed me to contribute to The State of Art Criticism (Elkins and Newman 2008) after I, perhaps rather cheekily, sent him an email to ask when the book was due to published and if it was possible to see an advance draft. I had come across mention of The State of Art Criticism in the first volume of the Art Seminar series, Art History versus Aesthetics (Elkins 2006). That book contained a list of all the forthcoming books in the series, with The State of Art Criticism comprising the still-to-be-published fourth volume. The excessively long 
email response I sent to him after he very kindly permitted me to view an almost complete draft of The State of Art Criticism was transformed into my contribution to the published book (Bowman 2008).

My concern here, however, is not to proffer biographical titbits and tales of good fortune. On the contrary, it is to draw upon the connection between the two books in order to spotlight another direction. Art History versus Aesthetics, as its very title suggests, took as its foundation a longstanding non-isomorphism, or even outright conflict, between the fields of art history and aesthetics in order to examine the conditions underpinning their general disinvolvement and, ultimately, to propose the possibility of fecund overlap. Broadly speaking, art history and aesthetics normally occupy different departments of the academic system even if their interests would appear to be convergent. The situation is far from absolute, to be sure, and it is a straightforward exercise to name major figures deeply engaged in art history and aesthetics in varying ways: Arthur Danto, Thierry de Duve, Whitney Davis, Michael Podro, Margaret Iversen, and Michael Ann Holly, Stephen Melville can all be enlisted here.

Art history's predominant lack of serious interest in aesthetics is mirrored in great measure by a similar situation within art criticism. Indeed, an awkwardly hybrid-titled potential sequel, The State of Art Criticism versus Aesthetics, can well be envisaged here. Again, such claims should not be uttered in a totalizing register insofar as exceptions can be easily registered; at stake are certainly general and perhaps also hegemonic tendencies. Our perspective on these matters, though, will be necessarily determined by how forcefully the distinction between aesthetics, on the one hand, and the philosophy of art, on the other, is maintained or refused. If it is provisionally tempting to affirm Danto as a major figure straddling art criticism and aesthetics, then such temptations are dampened when one recalls his longstanding defense of the philosophy of art against aesthetics-his elaboration of the "art world" (Danto 1964) as a concept and later discussion of indiscernibility in The Transfiguration of the Commonplace (Danto 1981) aim to show aesthetics, with its focus on sensuous properties, as being neither necessary nor sufficient as an explanatory framework for art. Further problematizing any such identification is that criticism and the philosophy of art have always seemed like carefully demarcated activities in Danto's output to the degree that, for all their obvious interconnections, it is as if there two Dantos writing about art: a journalistic Danto and an academic Danto, perhaps.

I have lingered on the example of Danto for mostly strategic reasons: partly to highlight the aesthetics/philosophy of art distinction and partly to highlight the separation of art criticism from the aesthetics/philosophy of art. But there is a further reason to allow the focus on Danto for another moment. During the course of the round table conversation transcribed in Art History versus Aesthetics, Danto testily replies to a comment just made by Thierry de Duve by saying:

That's exceedingly noble. But I don't see why the issue of Kant even has to arise in this conversation. If you ask a person who decorates a room why he does it, he might say it makes people feel better. Why would art historians pay attention to the aesthetic qualities of works of art? That's the question, not, "Shall we read Kant?_or, "Shall we burn Kant?". Kant is something that doesn't belong in this conversation. Beauty belongs in this conversation, but Kant belongs in the library. (Elkins 2006, p. 165)

Even presented out of context, various striking aspects immediately stand out. Kant is often construed as either the or one of the paradigmatic figures of aesthetics; although he, of course, did not originate the concept of aesthetics and, in crucial ways, modified the discourse around taste that underpinned British philosophy of the early eighteenth century, Kant is seen as a ground-breaking figure, whose aesthetic philosophy would set the benchmark that forced subsequent thinkers to "read with, through, and/or against" him (to borrow inexactly a Heideggerian formula). That Danto's longstanding rejection of aesthetics would be mirrored in antipathy towards Kant is hardly surprising. And although rather loosely, Danto has invested in the philosophical figure who is broadly viewed as proffering the most serious challenge to Kant, namely, Hegel. While Hegel's extensive discussion of architecture, sculpture, painting, music, and poetry have been published posthumously under the title of Hegel's Aesthetics: Lectures on Fine Art, Hegel's focus on art as historically-situated thinking through materials, in which a developed truth content is to be made manifest, rather than as sensuous artefacts that aim to give 
pleasure, would appear, at first glance, to position him—in Danto's eyes, at least—as contributing to the philosophy of art rather than aesthetics per se. De Duve, as an art historian who has significantly engaged in Kant in light of late-modernism and Duchamp, virtually constitutes Danto's polar opposite. And finally one might mention Danto's inclination to conceive aesthetics as almost pretheoretical, as barely amenable to discourse, as something whose role is to fulfill an ameliorative function ("makes people feel better") and perhaps ultimately exist at some remove from the ivory towers of philosophy. As he admits shortly afterward about his own late interest in aesthetics: "What really got me started in aesthetics at all—not as an academic discipline, but as a living thing —were the shrines that were set up all over New York City the day after 9/11" (Elkins 2006, p. 71, emphasis is mine; Danto 2003). Aesthetics, when it matters at all, is seemingly more vital for its distance from philosophers pouring over Kant.

But what provoked Danto's ire? That opening sarcastic comment, "That's exceedingly noble", was uttered in response to de Duve's summary of the importance that the concept of sensus communis, which "formulates a transcendental-I say transcendental, not utopian or anything like that-foundation for democracy and peace on earth" (Elkins 2006, p. 65). De Duve's playful reference to "peace on earth" was undoubtedly intended to set up the "good-natured laughter" that followed and is recorded in the transcript. And yet, something disappears in that laughter and is further dispatched into oblivion by the bitterness of Danto's "That's exceedingly noble". De Duve's "peace on earth" is funny and merits laughter-it is surely not ridiculous to imagine a twinkle in his eye as he said those words-but what that laughter displaces is the "foundation for democracy" and the rapid description of the sensus communis that came immediately before. It is notable that nobody picks up on that concept at all in the remainder of the discussion. Moreover, it is as if the laughter was occasioned not just by humor but also by embarrassment. From today's perspective, notions of a sensus communis can legitimately feel naïve, unrealistic, implausibly universalizing, historically outdated, or, at worse, as falsely underwriting an aesthetic ideology that is imposed by one hegemonic social class (the bourgeoise, say) upon another that is coded as "weaker" or as to be "dominated." Our sense of the public is more likely to be constituted by a high level of differentiation or agonism that ultimately derails the identarian singularity that one might associate with how the sensus communis has been philosophically imagined.

The laughter may also reflect the uncomfortable position that Kant has occupied within the art world. Much of this stems from Clement Greenberg's defense of medium specificity and formalism (Greenberg [1960] 1993) that strategically appealed to Kant during the 1960s, that is to say, in a historical conjuncture in which Greenberg's criticism, and modernism in general, was coming under an onslaught from an emergent generation of younger artists and critics. As is probably well recognized by now, Greenberg's reference to Kantian self-criticism in his 1960 essay "Modernist Painting" really takes from the opening pages of Kant's Critique of Pure Reason and its discussion of epistemology rather than aesthetics. Greenberg's subsequent references in his essays and seminars to Kant attempt to take up the disinterested judgment of taste in such a manner that it is used to buttress his support for post-painterly abstraction against the claims advanced by conceptual art and other movements (Greenberg 1999). Indeed, as de Duve (1996) suggests in his major essay “The Monochrome and the Blank Canvas", the breakdown of the modernist "paradigm" in the 1960s—even to see modernism as a paradigm, and therefore intrinsically replaceable — encouraged Greenberg to defend his criticism through a pretheoretical, absolutist aesthetic judgment that declared the rightness of his taste and, therefore, allowed little or no space for rejoinder. The sensus communis thus became Greenberg's shrinking circle of like-minded critics and artists; those who disagreed were excluded from the sensus commnis and simply designated as "wrong".

With the displacement of modernism by postmodernism, and the need to generate an art criticism that countered Greenberg's doctrine of medium specificity, a number of tendencies were collapsed together. By the early 1970s, younger artists and critics in the Anglo-American context perceived Greenberg, modernism, medium specificity, formalism, and aesthetics as all conjoined facets of a unitary discourse. Going beyond and rejecting modernism, then, necessarily entailed the dismissal of 
each of the other facets. Because art and criticism were producing that rejection, it was thus able to place itself at a remove and set up the art/criticism versus aesthetics—-the so-called anti-aesthetic-character of postmodernism. Ultimately, art criticism (or art theory) and aesthetics find themselves strenuously opposed in the manner that we find in Danto, and, correspondingly, Kant becomes the emblematic figure of aesthetics fiercely pushed aside.

Such sidelining, however, amounted to throwing the proverbial baby out with the bathwater. There is not enough space here to examine how concepts such as formalism and modernism were simplified, either for strategic reasons or due to imprecise analysis, and, consequently, misrepresented. Within art criticism, for example, it often appeared to be the case that Greenberg's Kant was taken to be Kant as if Greenberg communicated the ideas expressed in the Critique of Judgment accurately enough. In bringing this essay to a close, I wish to suggest briefly why it is worth rescuing the Kantian sensus communis from the laughter that swallowed it up after de Duve's defence of it. My hope in doing is this is that it may indicate a rationale for a rapprochement between art criticism and aesthetics. Furthermore, this may also allow us to begin speculatively envisaging a modality of intersubjective exchange different from the quasi-enforced connexionist protocols of post-Fordism. And finally, it may provide a glimmer of insight into why some contemporary art critics/theorists-such as Bishop (2012) and Tom Holert (2020), for instance-have explicitly opened a space for aesthetics in their writings.

Kant's sensus communis is intimately entwined with his comprehension that aesthetic judgment is a species of reflective judgment (Kant [1790] 2002). Bracketing the fact that reflective judgment is a concept deployed by Kant in differing ways (Danto 1997), it is most straightforwardly understood though its opposition to determinate judgment. In the case of a determinate judgment, a judgment is made because we have a general pre-established concept that allows us to judge something as an instance of that concept. The flat surface upon which I work I perceive as a table because I am familiar with the concept of tables; the four-legged creature that comes into my lockdown office is categorized as a cat because she fits the category of cats and so is not to be confused with a dog. Determinate judgments, thus, involve us recognizing the particular instance as an example of the general or universal concept. Reflective judgments, though, are judgments made when there is no, and perhaps cannot be, a corresponding general concept or rule. For Kant, beauty cannot be reduced to law-like appearances or a stable concept, and, therefore, there are no rules for divining whether the thing in front of you is beautiful or not.

Crucially, the absence of rules that govern how an aesthetic judgment is produced does not result in the conclusion that beauty is merely in the eye of the beholder for Kant-his aesthetics is not rooted in subjectivism, and this is where he departs from earlier figures such as Francis Hutcheson. Properly speaking, in order to be a judgment rather than merely an expression of opinion, it is necessary for the aesthetic judgment to claim some level of intersubjective validity. But the deepest motives of Kant's account here, it might be argued, stems from the difficulty of that intersubjectivity, rather than its imposition, in such a manner that is continuous with his overarching attempt to retain human freedom against a world whose operations seem almost irrevocably defined by quasi-mechanical necessity. Thus, aesthetic judgments are voiced in what might be apprehended as a first-person plural in which the judge speaks to and "for" a community, a sensus communis. But even if a sensus communis is posited by Kant as a transcendental foundation in the voicing of an aesthetic judgment, it does not take much pushing of his argument to propose that the existence of any such sensus communis is actively discovered - or not-in the very moment of voicing, and, importantly, sharing, our aesthetic judgment. The sensus communis as a transcendental condition of possibility prevents us from uttering aesthetic judgments into the void, while the sensus communis as a discovery that follows, potentially, from such utterances demonstrates what we share and constitutes the individual as a member of a community. As such, the sensus communis operates differently to the notion of the public sphere that was fostered during the Enlightenment and served as one of the social determinants for the emergence of art criticism (Habermas 1989). Kant does not supply his readers with a theory for performing aesthetic judgments; what he gives, on the contrary, is a philosophical account of why aesthetic judgment matters. 
We should, therefore, dispel any thought that the shared voices of the sensus communis amount to a suppression of difference between social agents or the forcing of one viewpoint upon others. That we discover what we might share is necessarily interdependent with the brute fact of our experiential finitude, thereby suggesting the need to conceive of acknowledgment as an interpretation of knowledge, hails from the intractability of difference (Gould 1982; Cavell [1979] 1999). Although her conception of aesthetics is indebted to Jacques Rancière, Bishop's references to aesthetics is predicated upon the possibility of a dissensual or agonistic community that dovetails with how we might grapple with Kant (and indeed, Rancière (2009) builds upon Friedrich Schiller (Schiller [1795] 2016), who was, of course, rethinking Kant's Critique of Judgment). Art criticism as a dialogue amid critic, artist, artwork, and the public can rediscover much about itself from aesthetics. And indeed, such an art criticism might be well-placed to think about the communicational and connexionist elements beyond its present post-Fordist utilization. That the current situation for art criticism hardly seems rosy in a moment where, as Foster (2020) states, Barthesian demystification appears to be powerless before a politics based around post-truth and post-shame modes, the need to reimagine a sensus communis becomes all the more pressing.

Thus, there might still be a place for art criticism, even if discussions on its condition often diagnose its current state as being underpinned by crisis. Co-emergent with the public sphere, art criticism once had a vital role to play in conceiving how the public can identify and govern itself insofar as artworks and other cultural forms were, in themselves, arenas where public identity is envisaged, produced, and displayed. An important parallel tale, centered around aesthetics, is related by Howard Caygill in his magisterial Art of Judgment (Caygill 1989), whereby the notion of taste stems from questions raised during the seventeenth and eighteenth centuries regarding how a multitude can self-govern in the absence of a Hobbesian monarch. Post-Fordism, crucially synchronous with the ballooning of social media and dependent upon the production of subjectivity, can be perceived as reactivating the question of what society or community is, or more precisely, could be. Art criticism and aesthetics during the eighteenth century, as separate but related discourses, sought to answer that question in light of the public sphere and the sensus communis, whilst recognizing that any community did not precede but was constituted by those answers. And yet, to a degree, the answers posed by art criticism and aesthetics were at a remove from the artwork, especially the visual artwork, reflecting a permanent worry about the conjuncture (or lack thereof) between theory and practice, the discursive and the visual, the temporal and the spatial. Today, post-Fordism's reliance upon, and promotion of, networking and communication indeed burdens any critical artistic practice with the danger of complicity. By the same token, art criticism's collaboration with the artwork runs the risk of narrowing the gap between post-Fordism and art criticism. In the domain of social media, perhaps, everyone is an art critic in waiting. But art criticism has to acknowledge its potential complicity, as well as examine the difference between collaboration between artworks and criticism, on the one hand, and collaboration between artists and critics, on the other. The former distinction can indicate aspects where the collaboration described above differs from the connexionist paradigm of post-Fordism. And, as I have suggested, rethinking its correspondence with aesthetics may allow art criticism to participate in an imagination of a sensus communis irreducible to post-Fordism's celebration of networking.

Funding: This research received no external funding.

Acknowledgments: I thank the peer reviewers whose comments helped bring this essay to completion.

Conflicts of Interest: The author declares no conflict of interest. 


\section{References}

Baker, George, Rosalind Krauss, Benjamin Buchloh, David Joselit, Andrea Fraser, James Meyer, Robert Storr, Hal Foster, John Miller, and Helen Molesworth. 2002. Round Table: The Present Conditions of Art Criticism. October 100: 200-28.

Baxandall, Michael. 1986. Patterns of Intention: On The Historical Explanation of Pictures. New Haven and London: Yale University Press.

Bishop, Claire. 2012. Artificial Hells: Participatory Art and the Politics of Spectatorship. London: Verso.

Boltanski, Luc. 2008. The Present Left and the Longing for Revolution. In Under Pressure: Pictures, Subjects, and the New Spirit of Capitalism. Edited by Daniel Birnbaum and Isabelle Graw. Berlin and New York: Sternberg Press.

Boltanski, Luc, and Eve Chiapello. 2005. The New Spirit of Capitalism. Translated by Gregory Elliot. New York: Verso.

Bowman, Matthew. 2008. The New Critical Historians of Art? In The State of Art Criticism. Edited by James Elkins and Michael Newman. New York: Routledge, pp. 289-95.

Carroll, Noël. 2009. On Criticism. Abingdon: Routledge.

Cavell, Stanley. 1999. The Claim of Reason: Wittgenstein, Skepticism, Morality, and Tragedy. Oxford: Oxford University Press. First published 1979.

Cavell, Stanley. 2002. Music Discomposed. In Must We Mean What We Say? Updated Edition. Cambridge: Cambridge University Press, pp. 180-212.

Caygill, Howard. 1989. Art of Judgment. New York: Blackwell Pub.

Clark, T. J. 1985. The Painting of Modern Life: Paris in the Art of Manet and His Followers. London: Thames and Hudson.

Danto, Arthur C. 1964. The Artworld. The Journal of Philosophy 61: 571-84. [CrossRef]

Danto, Arthur C. 1981. The Transfiguration of the Common Place: A Philosophy of Art. Cambridge: Harvard University Press.

Danto, Arthur C. 1997. After the End of Art: Contemporary Art and the Pale of History. Princeton: Princeton University Press.

Danto, Arthur C. 2003. The Abuse of Beauty: Aesthetics and the Concept of Art. Chicago: Open Court.

Davis, Whitney. 1996. Replications: Archaeology, Art History, Psychoanalysis. Edited by Richard W. Quinn. University Park: The Pennsylvania State University Press.

de Duve, Thierry. 1996. Kant after Duchamp. Cambridge: MIT Press.

Derrida, Jacques. 1976. Of Grammatology. Translated by Gayatri Chakravorty Spivak. Baltimore: John Hopkins University Press.

Diederichsen, Diedrich. 2010. Judgment, Objecthood, Temporality. In Judgment and Contemporary Criticism. Edited by Jeff Khonsary and Melanie O’Brian. Vancouver: Fillip/Artspeak, pp. 83-99.

Elkins, James, ed. 2006. Art History versus Aesthetics. New York: Routledge.

Elkins, James, and Michael Newman, eds. 2008. The State of Art Criticism. New York: Routledge.

Foster, Hal. 1996. The Artist as Ethnographer. In The Return of the Real: The Avant-Garde at the End of the Century. Cambridge: MIT Press.

Foster, Hal. 2020. What Comes after Farce? Art and Criticism at a Time of Debacle. New York: Verso.

Fraser, Andrea. 2006. From the Critique of Institutions to an Institution of Critique. In Institutional Critique and after. Edited by John C. Welchman. Zurich: JRP/Ringier, pp. 123-35.

Fried, Michael. 1998. Art and Objecthood. In Art and Objecthood: Essays and Reviews. Chicago: University of Chicago Press, pp. 148-72.

Gould, Timothy. 1982. The Audience of Originality. In Essays on Kant's Aesthetics. Edited by Paul Guyer and Ted Cohen. Chicago: University of Chicago Press, pp. 179-93.

Graw, Isabelle. 2012. In the Grip of the Market? On the Relative Heteronomy of Art, the Art World, and Art Criticism. In Contemporary Art and its Commercial Markets: A Report on Current Conditions and Future Scenarios. Edited by Maria Lind and Olav Velthuis. Berlin: Sternberg Press, pp. 183-205.

Greenberg, Clement. 1993. Modernist Painting. In Collected Essays and Criticism, Volume 4: Modernism with a Vengeance, 1957-1969. Edited by John O'Brian. Chicago and London: University of Chicago Press. First published 1960.

Greenberg, Clement. 1999. Homemade Esthetics: Observations on Art and Taste. Oxford: University of Oxford Press. 
Habermas, Jürgen. 1989. The Structural Transformation of the Public Sphere. Translated by Thomas Burger. Cambridge: Polity.

Holert, Tom. 2011. Artistic Research: Anatomy of an Ascent. In Texte zur Kunst. Isabelle Graw: Berlin.

Holert, Tom. 2020. Knowledge Beside Itself: Contemporary Art's Epistemic Politics. Berlin and New York: Sternberg Press.

Kant, Immanuel. 2002. Critique of the Power of Judgment. Translated by Paul Guyer, and Eric Matthews. Cambridge: Cambridge University Press. First published 1790.

Krauss, Rosalind. 1986. The Originality of the Avant-Garde and Other Modernist Myths. Cambridge: MIT Press.

Philippe, Lacoue-Labarthe, and Jean-Luc Nancy. 1988. The Literary Absolute: The Theory of Literature in German Romanticism. Translated by Philip Barnard, and Cheryl Lester. Albany: State University of New York Press, Firtst published 1978.

Lazzarato, Maurizio. 1996. Immaterial Labour. In Radical Thought in Italy: A Potential Politics. Edited by Paolo Virno and Michael Hardt. Translated by Maurizia Boscagli, Maurizia Boscagli, Cesare Casarino, Paul Colilli, Ed Emory, Michael Hardt and Michael Turits. Minneapolis: University of Minnesota Press, pp. 142-57.

Owens, Craig. 1979. Earthwords. October 10: 121-30. [CrossRef]

Owens, Craig. 1980. The Allegorical Impulse: Towards a Theory of Postmodernism. October 12: 67-86. [CrossRef]

Rancière, Jacques. 2009. Dissensus: On Politics and Aesthetics. Translated by Steve Corcoran. London and New York: Continuum.

Schiller, Friedrich. 2016. On the Aesthetic Education of Man. Translated by Keith Tribe. Introduction and Notes by Alexander Schmidt. London: Penguin. First published 1795.

Smithson, Robert. 1996. The Collected Writings. Edited by Jack Flam. Berkeley and London: University of California Press.

Stephanson, Anders. 1992. Interview with Craig Owens. In Beyond Recognition: Representation, Power, and Culture. Edited by Craig Owens and Scott Bryson. Introduction by Simon Watney. Berkeley: University of California Press, pp. 298-315.

(C) 2020 by the author. Licensee MDPI, Basel, Switzerland. This article is an open access article distributed under the terms and conditions of the Creative Commons Attribution (CC BY) license (http://creativecommons.org/licenses/by/4.0/). 